\title{
Autologous MAGE-A3-specific HLA-A*01- Restricted T Cell Receptor Gene Engineered Lymphocytes
}

National Cancer Institute

\section{Source}

National Cancer Institute. Autologous MAGE-A3-specific HLA-A*01-Restricted T Cell

Receptor Gene Engineered Lymphocytes. NCI Thesaurus. Code C116711.

Human autologous T-lymphocytes transduced with a retroviral vector encoding a $\mathrm{T}$-cell receptor (TCR) specific for the human leukocyte antigen (HLA)-A*01-restricted, human melanoma-associated antig en A3 (MAGE-A3), with potential antineoplastic activity. Peripheral blood mononuclear cells (PBMCs) are isolated from a patient, transduced with an anti-MAGE-A3-HLA-A*01 restricted TCR, expanded ex vivo, and reintroduced into the HLA-A*01-positive patient. Then, the autologous MAGE-A3-specific, HLA-A*01-restricted TCR gene eng ineered lymphocytes bind to tumor cells expressing the MAGE-A3 antigen, which may increase cell death and halt the growth of MAGE-A3-expressing cancer cells. The tumor-associated antigen MAGE-A3 is overexpressed by a variety of cancer cell types. 